\title{
IS THERE A RELATION BETWEEN ALVEOLAR RIDGE DIMENSIONS AND BUCCAL UNDERCUT IN THE ANTERIOR MAXILLA? *
}

\author{
ANTERİOR MAKSİLLADA ALVEOLER KRET BOYUTLARI VE BUKKAL ANDIRKAT \\ ARASINDA BİR İLISŞKI VAR MI? *
}

Uzm. Dt. Fatma Nur YILDIZ

Prof. Dr. Zühre Zafersoy AKARSLAN*

Makale Kodu/Article code: 4220

Makale Gönderilme tarihi; 18.11 .2019

Kabul Tarihi: 27.02.2020

DOI : $10.17567 /$ ataunidfd.695391
Fatma Nur Yıldız: ORCID ID: 0000-0002-9467-5572

Zühre Zafersoy Akarslan: ORCID ID: 0000-0001-9237-412X

\section{ABSTRACT}

Aim: The aim of this study was to investigate of the relation between the alveolar ridge dimensions and buccal undercut in the anterior maxilla.

Material and Methods: Cone-beam computed tomography images of 150 patients ( 97 females, 53 males), aged between 1640 years having full anterior dentition at the maxilla were evaluated. Six-hundred cross-sectional images were obtained from the regions between central, lateral and canine teeth in the right and left maxilla. The alveolar height and width, and the presence and depth of buccal undercut in these regions were assessed.

Results: It was found that the prevalence of buccal undercuts in different regions ranged from $74 \%$ to $84 \%$ on average. Compared to males, the presence of buccal undercut was found to be significantly higher in females in the regions of between right lateral-canine teeth, left central-lateral teeth and left lateral-canine teeth $(p<0.05)$. A significant positive correlation was determined between alveolar height and coronal alveolar width with buccal undercut depth for all the regions in females $(p<0.01)$. However, a significant positive correlation was only found between coronal alveolar width and buccal undercut depth in the regions of between right central-lateral teeth, left lateral-canine teeth $(p<0.05)$ and right lateral-canine teeth $(p<0.01)$ in males.

Conclusion: The dimensions of the alveolar ridge had an effect on the buccal undercut depth. The buccal undercut depth increased when alveolar height and coronal alveolar width increased in females, however it increased only when the coronal alveolar width increased in males.

Key Words: Prosessus alveoleris, morphology, cone-beam computed tomography.

ÖZ

Amaç: $\mathrm{Bu}$ çalışmanın amacı maksilla anterior bölgede alveoler kret boyutları ile bukkal andırkat arasındaki ilişkinin araştırılmasıdır.

Gereç ve Yöntem: Maksillada tam anterior dentisyona sahip, 16-40 yaşları arasındaki 150 hastaya (97 kadın, 53 erkek) ait konik ışınlı bilgisayarlı tomografi görüntüleri değerlendirildi. Sağ ve sol maksillada santral, lateral ve köpek dişleri arasındaki bölgelerden altı yüz krosseksiyonel kesit görüntüsü elde edildi. Bu bölgelerde alveoler kret yüksekliği ve genişliği ile bukkal andırkat varlığı ve derinliği değerlendirildi.

Bulgular: Farklı bölgelerde bukkal andırkat görülme sıkığının ortalama\% 74 ile \% 84 arasında değiştiği bulundu. Kadınlarda sağ lateral-kanin, sol santral-lateral, sol lateral-kanin dişler arası bölgelerde bukkal andırkat varlığı erkeklere kıyasla anlamlı olarak daha yüksek bulundu $(\mathrm{p}<0.05)$. Kadınlarda tüm bölgelerde alveoler yükseklik ve koronal alveoler genişlik ile bukkal andırkat derinliği arasında anlamlı pozitif korelasyon belirlendi $(p<0.01)$. Bununla birlikte, erkeklerde sadece sağ santral-lateral, sol lateral-kanin $(p<0.05)$ ve sağ lateral-kanin $(p<0.01)$ dişler arası bölgelerde koronal alveoler genişlik ile bukkal andırkat derinliği arasında anlamlı pozitif korelasyon bulundu $(p<0.01)$.

Sonuç: Alveoler kret boyutları bukkal andırkat derinliği üzerinde etkili olmuştur. Kadınlarda koronal alveoler genişlik ve alveoler yükseklik arttıkça bukkal andırkat derinliği artmıştır bununla birlikte, erkeklerde sadece koronal alveoler genişlik arttıkça bukkal andırkat derinliği artmıştır.

Anahtar Kelimeler: Alveoler bombe, morfoloji, cone-beam computed tomography

* Gazi Üniversitesi, Diş Hekimliği Fakültesi, Ağız, Diş ve Çene Radyolojisi A.D. Emek, Ankara

\#Acknowledgements: This study is a part of a master thesis accepted on 7.02.2018. This study has been presented as an oral presentation in the 23th International Dental Congress of TDB in Turkey in 2018

Kaynakça Bilgisi: Yıldız FN, Zafersoy Akarslan Z. Anterior maksillada alveoler kret boyutları ve bukkal andırkat arasında bir ilişki var mı? Atatürk Üniv Diş Hek Fak Derg 2020; 30: 174-80.

Citation Information: Yildiz FN, Zafersoy Akarslan Z. Is there a relation between alveolar ridge dimensions and buccal undercut in the anterio maxilla? J Dent Fac Atatürk Uni 2020; 30: 174-80. 


\section{INTRODUCTION}

The volume, density and trabecule organization of the maxilla and mandible considerably varies from person to person ${ }^{1}$. Determination of the density, height, width and morphology of alveolar bone is very important for choosing the surgical technique and method $^{2}$. Different studies used various methods for identifying the quality of alveolar bone. The quality of bone in both jaws between the posterior and anterior regions is not the same. The quality of bone in the posterior region is generally worse compared to the anterior region ${ }^{3-8}$. Beside these studies, the number of studies evaluating the morphology of the anterior maxilla is quietly little ${ }^{2}$.

In the anterior region, providing stabilization of the implant and aesthetic of the restorations are difficult due to narrower alveolar process compared to the posterior region ${ }^{9}$. Additionally, presence of buccal undercut increases perforation risk of the alveolar ridge and points out the need for graft procedures ${ }^{2}$. In the lateral incisor region, the risk of buccal plate perforation is very high because the lateral incisor has the highest incidence of buccal undercut compared to the other teeth in the anterior maxilla ${ }^{2}$. Whence, risky anatomical areas and patients should be carefully examined with cross-sectional imaging techniques for more accurate treatment planning ${ }^{10,11}$.

Conventional radiographic techniques have been used as standard methods for implant treatment planning till the improvement of cross-sectional imaging techniques ${ }^{12}$. Panoramic and/or periapical radiographs may be inadequate because they provide a two-dimensional image of mesial-distal and occlusalapical dimensions of the alveolar ridge about implant site. However, these radiographic techniques don't allow assessment of the bucco-lingual dimension and undercuts $^{13}$. Nowadays, cone beam computed tomography $(\mathrm{CBCT})$ is commonly preferred to assess the implant site ${ }^{14}$.

A preoperative evaluation of the anterior maxilla is very important for choice of optimum treatment approach and preventing of surgical complications $^{2}$. To our knowledge the number of studies that evaluated buccal undercut in the maxilla anterior is quietly little in the literature. We hypothesized that the dimensions of alveolar ridge and the presence and depth of buccal undercut may vary by gender and age. The aim of the present study is to evaluate bilaterally the height and width of the alveolar ridge, and the presence and depth of buccal undercut in the maxillary anterior region.

\section{MATERIAL AND METHODS}

Ethical approval was obtained from the Ethics Commitee of Gazi University before starting to the study (Date: 28/06/2016, Number: E.80628). This work was done in accordance with the principles defined in the Declaration of Helsinki, including all revisions.

150 CBCT images present in the archive of the radiology department belonging to $97 \quad(64,7 \%)$ females and $53(35,3 \%)$ males with an age range of $16-40$ years old $(26.07 \pm 6.661)$ who had undergone radiologic examination between January 2014 and December 2016 were assessed. Images were taken with the Planmeca Promax 3D Mid CBCT unit (Planmeca, Helsinki, Finlandiya). The technical parameters of CBCT scans were $90 \mathrm{kVp}, 12 \mathrm{~mA}, 0,4$ $\mathrm{mm}^{3}$ voxels and $20 \times 10$ or $20 \times 17 \mathrm{~cm}$ field of view.

Subjects were selected according to the following inclusion criteria:

1-no systemic/endocrine diseases that influenced bone metabolism²

2-no local conditions that may affect bone at anterior maxilla, e.g., moderate to severe periodontal disease, cyst, tumour, fracture ${ }^{2}$

3-No missing teeth in the anterior maxilla and maximum 2 teeth missing in the premolar and molar region of the maxilla (excluding third molars) ${ }^{15}$.

All CBCT images were oriented by making the occlusal plane parallel to the floor (Figure 1). Crosssectional slices perpendicular to alveolar ridge were prepared from the alveolar crest between the central and lateral teeth and canine and lateral teeth on the axial image (Figure 2).

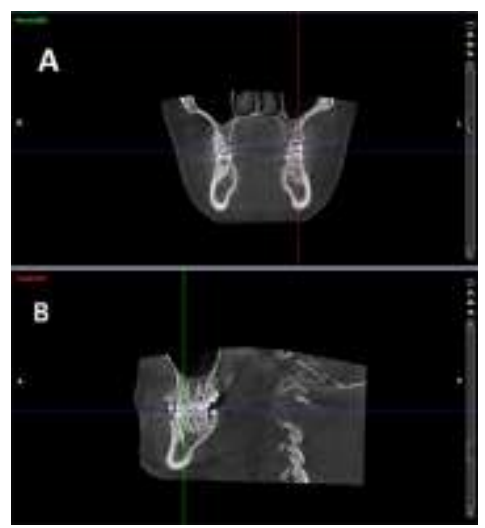

Figure 1. Coronal (a) and sagittal (b) view of occlusal plane 
The region between the maxillary right central incisor and lateral incisor (R1-R2), the maxillary right lateral incisor and canine (R2-R3), the maxillary left central incisor and lateral incisor (L1-L2), and the maxillary left lateral incisor and canine (L2-L3) were measured. All of the measurements were performed by a research assistant working in the Radiology department according to the following steps:

1. Alveolar height

"A line was drawn from alveolar crest paralleling with the long axis of alveolar ridge. The distance from alveolar crest to the floor of nasal fossa was defined as alveolar height" ${ }^{2}$ (Figure 3).

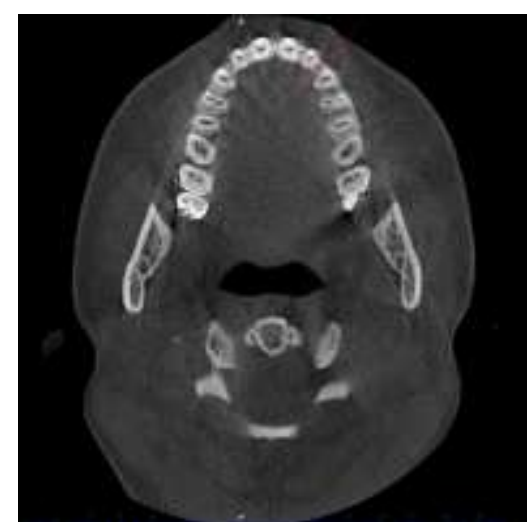

Figure 2. Axial view of the maxillary arch. (The red line is perpendicular to the alveolar ridge)

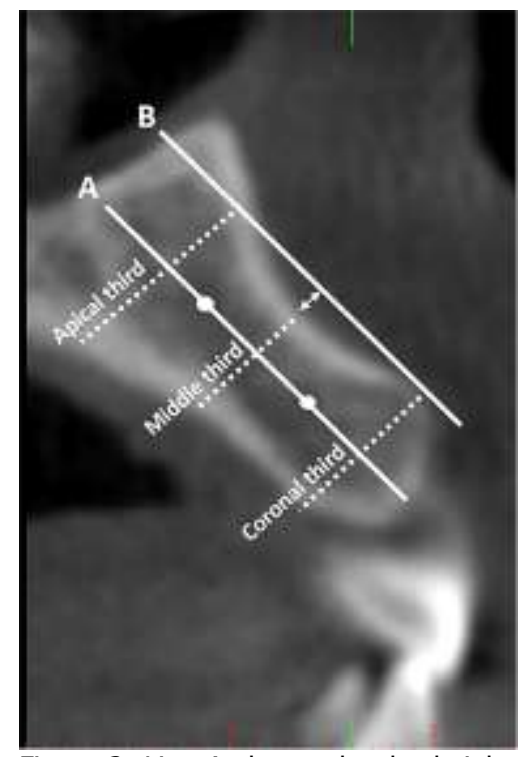

Figure 3. Line A shows alveolar height. The alveolar height is divided into three parts (shown by white dots). Dashed line shows apical, middle and coronal alveolar width. Line B was drawn tangent to buccal cortical plate and parallel to the long axis of alveolar ridge. The distance between the deepest point and Line B shows buccal undercut depth (twoheaded arrow).

\section{Alveolar width}

"Alveolar height was divided into coronal, middle, and apical third. In the middle of each third, a line was drawn perpendicular to the long axis of alveolar ridge. The distance between buccal and palatal cortical plate was defined as alveolar width" ${ }^{2}$ (Figure 3).

\section{Buccal undercut depth}

"For a tooth identified to have buccal undercut, a line tangent to buccal cortical plate and parallel to the long axis of alveolar ridge was drawn. The distance from the deepest point of the buccal undercut to the aforementioned line was defined as the buccal undercut depth"2 (Figure 3).

\section{Statistical analysis}

Descriptive analysis was calculated for demographic data and measurements. KolmogorovSmirnov test was performed to identify the normality of the data. Independent samples t-test was utilized to determined statistical difference among the genders groups. One-way ANOVA was utilized to determined statistical difference among the regions and age groups. If there was statistical difference between these groups, Tukey's honestly significant difference (HSD) post-hoc test was used. Buccal undercut depth was assessed by Mann Whitney-U test among genders. Any relation between alveolar height and width with buccal undercut depth was evaluated by Pearson ci-square test. Two weeks later, 30 randomly selected cases were re-measured by the same investigator. Intraclass correlation coefficient was calculated in order to test intra-observer reliability. The significance coefficient was accepted as 0.05 . Statistical analysis was performed with IBM SPSS v.22 program (Statistical Package for Social Science, IBM Corporation, NY-USA).

\section{RESULTS}

There was no significant difference between the repeated measurements of the 30 patients indicating that intra-observer reliability was high ( $r>0.9)$. The height and width of the alveolar ridge did not show significant difference between symmetric regions ( $p>0.05$ ) (Table 1$)$. The coronal alveolar width was found to be significantly higher between the lateral and canine teeth compared to between the central and lateral teeth in the right and left side $(p<0.05)$ (Table 2). Alveolar height in the R2-R3 and $\mathrm{L} 2-\mathrm{L} 3$ regions, coronal alveolar width in the R1-R2 and

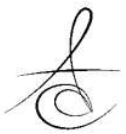


L2-L3 regions, and middle and apical alveolar widths in all regions were significantly higher in males $(p<0,05)$ (Table 1$)$.

To evaluate the effect of age, patients divided into three age groups including $16-20$ years ( $n: 35)$, 21-30 years ( $n: 69)$ and $31-40$ years $(n: 46)$. Coronal alveolar width was found to be significantly higher only in the L2-L3 region in patients aged $16-20$ compared to $21-30(p<0.05)$ (Table 3).

Buccal undercut was found in $84 \%$ in the $\mathrm{R} 2-\mathrm{R} 3$ region, $76.67 \%$ in the $\mathrm{R} 1-\mathrm{R} 2$ region, $74 \%$ in the $\mathrm{L} 1-\mathrm{L} 2$ region and $82 \%$ in the $\mathrm{L} 2-\mathrm{L} 3$ region in all patients (Table 4). Compared to males, the presence of buccal undercut was found to be significantly higher in females in the R2-R3, L1-L2 and L2-L3 regions (Table 4 ). The buccal undercut depth did not show significant differences among regions ( $p$ $>0.05$ ). It was significantly higher for all regions in females compared to males $(p<0.05)$ (Table 1$)$.

A significant positive correlation was found between alveolar height and coronal alveolar width with buccal undercut depth for all the regions in females $(p<0.01)$. However, a significant positive correlation was only find between coronal alveolar width and buccal undercut depth in the R1-R2, L2-L3 $(p<0.05)$ and $R 2-R 3 \quad(p<0.01)$ and regions in males (Table 5).
Table 2. Comparison between measurements of coronal alveolar width in the regions

\begin{tabular}{ccc}
\hline Region & Gender & $\mathbf{p}^{\text {ph }}$ \\
\hline R2-R3 and R1-R2 & female & $\mathbf{0 . 0 0 0}^{*}$ \\
R2-R3 and L2-L3 & male & $\mathbf{0 . 0 1 8}^{*}$ \\
& female & 0.559 \\
R1-R2 and L1-L2 & male & 0.958 \\
& female & 0.972 \\
L1-L2 and L2-L3 & male & 0.914 \\
& female & $\mathbf{0 . 0 0 5}^{*}$ \\
& male & $\mathbf{0 . 0 1 2}^{*}$ \\
\hline
\end{tabular}

$\mathrm{p}^{\text {ph: }}$ posthoc testi (Tukey HSD), $*: p<0.05, \mathrm{R} 1$, right central incisor; R2, right lateral incisor; R3, right canine; L1, left central incisor; L2, left lateral incisor; L3,left canine.

\section{DISCUSSION}

Determination of the density, height, width and morphology of alveolar bone is very important for choosing the appropriate surgical technique and method $^{2}$. Evaluation of the site of implant using cone beam computed tomography before treatment planning is commonly practiced ${ }^{14}$. There are limited number of studies in the literature which evaluates the size and morphology of alveolar ridge in anterior

Table 1. Means and standard deviations of measurements, comparison between measurements of genders and regions

\begin{tabular}{|c|c|c|c|c|c|c|}
\hline & Gender & R2-R3 (mm) & R1-R2 (mm) & L1-L2 (mm) & L2-L3 (mm) & $\mathbf{p}^{\mathbf{a}}$ \\
\hline \multirow{3}{*}{ alveolar height } & female & $19.09( \pm 2.42)$ & $19.08( \pm 2.51)$ & $19.03( \pm 2.49)$ & $19.10( \pm 2.42)$ & 0.997 \\
\hline & male & $20.26( \pm 2.46)$ & $19.82( \pm 2.49)$ & $19.66( \pm 2.26)$ & $20.10( \pm 2.40)$ & 0.577 \\
\hline & $\mathrm{p}^{\mathrm{t}}$ & 0.006* & 0.088 & 0.124 & 0.016* & \\
\hline \multirow[b]{2}{*}{$\begin{array}{c}\text { coronal alveolar } \\
\text { width }\end{array}$} & female & $6.94( \pm 0.87)$ & $6.42( \pm 0.78)$ & $6.37( \pm 0.81)$ & $6.78( \pm 0.93)$ & $0.000^{*}$ \\
\hline & $\begin{array}{c}\text { male } \\
\mathrm{p}^{\mathrm{t}}\end{array}$ & $\begin{array}{c}7.23( \pm 1.03) \\
0.074 \\
\end{array}$ & $\begin{array}{c}6.74( \pm 0.74) \\
\mathbf{0 . 0 1 7}^{*} \\
\end{array}$ & $\begin{array}{c}6.63( \pm 0.76) \\
0.057 \\
\end{array}$ & $\begin{array}{c}7.14( \pm 0.85) \\
\mathbf{0 . 0 2 0} \\
\end{array}$ & $0.000^{*}$ \\
\hline \multirow{3}{*}{$\begin{array}{l}\text { middle alveolar } \\
\text { width }\end{array}$} & female & $7.12( \pm 1.01)$ & $7.02( \pm 0.98)$ & $6.97( \pm 0.98)$ & $7.04( \pm 1.00)$ & 0.737 \\
\hline & male & $7.98( \pm 1.07)$ & $8.17( \pm 1.09)$ & $8.33( \pm 1.07)$ & $8.14( \pm 1.05)$ & 0.435 \\
\hline & $\mathrm{p}^{\mathrm{t}}$ & $0.000^{*}$ & $0.000^{*}$ & $0.000^{*}$ & $0.000^{*}$ & \\
\hline \multirow{3}{*}{$\begin{array}{l}\text { apical alveolar } \\
\text { width }\end{array}$} & female & $9.83( \pm 1.68)$ & $10.35( \pm 1.53)$ & $10.26( \pm 1.62)$ & $10.00( \pm 1.68)$ & 0.099 \\
\hline & male & $11.47( \pm 2.01)$ & $11.77( \pm 1.64)$ & $11.78( \pm 1.59)$ & $11.65( \pm 1.92)$ & 0.797 \\
\hline & $\mathrm{p}^{\mathrm{t}}$ & $0.000^{*}$ & $0.000^{*}$ & $0.000^{*}$ & $0.000^{*}$ & \\
\hline \multirow{3}{*}{ buccal undercut depth } & female & $0.79( \pm 0.52)$ & $0.63( \pm 0.45)$ & $0.64( \pm 0.50)$ & $0.69( \pm 0.48)$ & 0.341 \\
\hline & male & $0.56( \pm 0.48)$ & $0.48( \pm 0.49)$ & $0.40( \pm 0.37)$ & $0.50( \pm 0.46)$ & 0.441 \\
\hline & $\mathrm{p}^{\mathrm{m}}$ & $0.027^{*}$ & $0.016^{*}$ & $0.003^{*}$ & $0.006^{*}$ & \\
\hline
\end{tabular}

$p^{a}$ : oneway anova; $p^{t}$ independent samples $t$-test; $p^{m} ;$ mann whitney-u test; $*$; $p<0.05$

R1, right central incisor; R2, right lateral incisor; R3, right canine; L1, left central incisor; L2, left lateral incisor; L3, left canine. 
Table 3. Comparison between measurements of age groups

\begin{tabular}{cccccc}
\hline & Age groups & $\mathbf{R 2 - R 3}(\mathbf{m m})$ & $\mathbf{R 1 - R 2}(\mathbf{m m})$ & $\mathbf{L 1 - L 2}(\mathbf{m m})$ & $\mathbf{L 2}-\mathbf{L 3}(\mathbf{m m})$ \\
\hline alveolar height & $16-20$ & $19.45( \pm 2.47)$ & $19.44( \pm 2.52)$ & $19.18( \pm 2.52)$ & $19.43( \pm 2.39)$ \\
& $21-30$ & $19.62( \pm 2.58)$ & $19.51( \pm 2.45)$ & $19.41( \pm 2.33)$ & $19.53( \pm 2.50)$ \\
& $31-40$ & $19.35( \pm 2.41)$ & $19.01( \pm 2.64)$ & $19.06( \pm 2.51)$ & $19.35( \pm 2.47)$ \\
& $\mathrm{p}^{\mathrm{a}}$ & 0.846 & 0.563 & 0.739 & 0.927 \\
\hline coronal alveolar width & $16-20$ & $7.23( \pm 0.98)$ & $6.68( \pm 0.76)$ & $6.42( \pm 0.93)$ & $7.26( \pm 0.98)$ \\
& $21-30$ & $6.92( \pm 0.98)$ & $6.51( \pm 0.85)$ & $6.47( \pm 0.76)$ & $6.78( \pm 0.90)$ \\
& $31-40$ & $7.08( \pm 0.81)$ & $6.46( \pm 0.67)$ & $6.48( \pm 0.77)$ & $6.83( \pm 0.85)$ \\
& $\mathrm{p}^{\mathrm{a}}$ & 0.259 & 0.417 & 0.945 & $\mathbf{0 . 0 3 4}$ \\
\hline middle alveolar width & $16-20$ & $7.58( \pm 1.12)$ & $7.59( \pm 1.30)$ & $7.48( \pm 1.22)$ & $7.61( \pm 1.06)$ \\
& $21-30$ & $7.38( \pm 1.22)$ & $7.47( \pm 1.16)$ & $7.49( \pm 1.23)$ & $7.47( \pm 1.18)$ \\
& $31-40$ & $7.38( \pm 0.92)$ & $7.24( \pm 1.03)$ & $7.35( \pm 1.16)$ & $7.24( \pm 1.13)$ \\
& $\mathrm{p}^{\mathrm{a}}$ & 0.645 & 0.371 & 0.815 & 0.339 \\
\hline apical alveolar width & $16-20$ & $10.66( \pm 2.13)$ & $11.33( \pm 1.87)$ & $10.88( \pm 1.84)$ & $10.92( \pm 2.06)$ \\
& $21-30$ & $10.52( \pm 2.10)$ & $10.88( \pm 1.63)$ & $10.92( \pm 1.74)$ & $10.68( \pm 1.99)$ \\
& $31-40$ & $10.06( \pm 1.56)$ & $10.45( \pm 1.63)$ & $10.55( \pm 1.76)$ & $10.18( \pm 1.70)$ \\
& $\mathrm{p}^{\mathrm{a}}$ & 0.329 & 0.069 & 0.524 & 0.204 \\
\hline buccal undercut depth & $16-20$ & $0.85( \pm 0.36)$ & $0.70( \pm 0.42)$ & $0.78( \pm 0.37)$ & $0.86( \pm 0.47)$ \\
& $21-30$ & $0.82( \pm 0.48)$ & $0.73( \pm 0.41)$ & $0.71( \pm 0.41)$ & $0.70( \pm 0.41)$ \\
& $31-40$ & $0.89( \pm 0.48)$ & $0.83( \pm 0.36)$ & $0.79( \pm 0.39)$ & $0.77( \pm 0.39)$ \\
& $\mathrm{p}^{\mathrm{a}}$ & 0.782 & 0.402 & 0.593 & 0.278 \\
\hline
\end{tabular}

$\mathrm{p}^{\mathrm{a}}$ : oneway anova; ${ }^{\mathrm{p}}<0.05$

$\mathrm{R} 1$, right central incisor; R2, right lateral incisor; R3, right canine; L1, left central incisor; L2, left lateral incisor; L3, left canine.

Table 4. Rate of buccal undercut presence, comparison between buccal undercut of genders

\begin{tabular}{ccccccc}
\hline \multirow{2}{*}{ Region } & \multirow{2}{*}{ Gender } & \multicolumn{2}{c}{ Present } & \multicolumn{2}{c}{ Absent } & \multirow{2}{*}{$\mathbf{p}^{\text {chi }}$} \\
& & $\mathbf{n}$ & $\mathbf{\%}$ & $\mathbf{n}$ & $\mathbf{\%}$ & \\
\hline R2-R3 & female & 87 & 89.69 & 10 & 10.31 & \\
& male & 39 & 73.58 & 14 & 26.42 & $\mathbf{0 . 0 1 0}^{*}$ \\
& total & 126 & 84.00 & 24 & 16.00 & \\
R1-R2 & female & 79 & 81.44 & 18 & 18.56 & \\
& male & 36 & 67.92 & 17 & 32.08 & 0.061 \\
& total & 115 & 76.67 & 35 & 23.33 & \\
L1-L2 & female & 77 & 79.38 & 20 & 20.62 & \\
& male & 34 & 64.15 & 19 & 35.85 & \\
& total & 111 & 74.00 & 39 & 26.00 & \\
L2-L3 & female & 85 & 87.63 & 12 & 12.37 & \\
& male & 38 & 71.70 & 15 & 28.30 & $\mathbf{0 . 0 1 5 *}$ \\
& total & 123 & 82.00 & 27 & 18.00 & \\
\hline
\end{tabular}

$\mathrm{p}^{\text {chi }}$ : Pearson Chi-Square Tests; $*$ : $p<0.05$

$\mathrm{R} 1$, right central incisor; R2, right lateral incisor; R3, right canine; L1, left central incisor; L2, left lateral incisor; L3, left canine.

maxilla using $\mathrm{CBCT}^{2,16-18}$. In this study, the height and width of the alveolar ridge, and the presence and depth of buccal undercut were evaluated bilaterally in the anterior maxilla from the CBCT images present in the archive of the Oral and Maxillofacial Radiology Department.
Table 5. Correlation between buccal undercut depth and alveolar ridge dimensions

\begin{tabular}{cccccc}
\hline & $\begin{array}{c}\text { Gend } \\
\text { er }\end{array}$ & R2-R3 & R1-R2 & L1-L2 & L2-L3 \\
\hline \multirow{4}{*}{ alveolar height } & femal & $\mathbf{0 . 3 8 6}$ & $\mathbf{0 . 4 0 7}$ & $\mathbf{0 . 3 9 8}$ & $\mathbf{0 . 4 9 8}$ \\
& e & $* *$ & $* *$ & $* *$ & $* *$ \\
& male & 0.307 & 0.130 & -0.077 & 0.013 \\
femal & $\mathbf{0 . 4 3 9}$ & $\mathbf{0 . 4 4 4}$ & $\mathbf{0 . 4 6 1}$ & $\mathbf{0 . 5 9 5}$ \\
$\begin{array}{c}\text { coronal alveolar } \\
\text { width }\end{array}$ & e & $* *$ & $* *$ & $* *$ & $* *$ \\
& male & $\mathbf{0 . 5 0 3}$ & $\mathbf{0 . 3 5 2}$ & 0.212 & $\mathbf{0 . 3 2 7}$ \\
& & $* *$ & $*$ & & $*$ \\
\hline
\end{tabular}

$*: \mathrm{p}<0.05 ; * *: \mathrm{p}<0.01$

$\mathrm{R} 1$, right central incisor; R2, right lateral incisor; R3, right canine; L1, left central incisor; L2, left lateral incisor; L3, left canine.

Alveolar width may show differences in various parts of the alveolar ridge due to the concavity formed by the lateral fossa in anterior maxilla. Based on this situation, we measured alveolar width separately for coronal, middle and apical regions as in the study of Zhang et al. ${ }^{2}$. Only the coronal alveolar width was found to be significantly higher in the area between lateral and canine teeth compared to the area between the central and lateral teeth bilaterally. Zhang et al. ${ }^{2}$ calculated mean alveolar width and 
reported that alveolar width was significantly lowest in the lateral incisor area, although alveolar width were evaluated separately for coronal, middle and apical regions. There are various studies in the literature that assess alveolar width using $\mathrm{CBCT}$ at a distance of 2-8 $\mathrm{mm}$ from cemento-enamel junction or alveolar crest ${ }^{16}$, 17. In these studies, alveolar width was evaluated in a limited part of the alveolar ridge with different methods in order to the placement of orthodontic mini-implants. In our study, coronal alveolar width was found to be higher in R1-R2 and L2-L3 regions, middle and apical alveolar width was higher in all regions in males compared to females. It was reported in the study by Zhang et al. ${ }^{2}$ that the mean alveolar width was significantly higher in males compared to females in all regions.

The presence of buccal undercut increases the risk of alveolar bone perforation or indicates a need for additional grafting procedures ${ }^{2}$. Morphological features such as bone undercuts or concavities of the alveolar bone that may be overlooked at clinical examination are clearly observed with cross-sectional imaging. Identification of the height and the width of the alveolar bone, along with the inclination of the bone contours, is particularly beneficial in preoperative planning ${ }^{13}$. In this study, buccal undercut was found in $84 \%$ in the R2-R3 region, $76.67 \%$ in the $\mathrm{R} 1-\mathrm{R} 2$ region, $74 \%$ in the $\mathrm{L} 1-\mathrm{L} 2$ region and $82 \%$ in the L2-L3 region in all patients. The presence of buccal undercut was significantly higher in females compared to males in most of the regions. Zhang et al. $^{2}$ detected buccal undercut in $41 \%$ of the central incisors, $77 \%$ of lateral incisors and $33 \%$ of canines and reported that the lateral incisor has the highest incidence of buccal undercut. No significant difference was found among the regions in terms of buccal undercut depth. Our results are consistent with the study of Zhang et. al. ${ }^{2}$ The depth of buccal undercut was found to be significantly higher in females in all the regions compared to males. Chung et al. ${ }^{18}$ reported that buccal undercut was found in the entire central, lateral and canine teeth region of 11 cadavers on both sides and the deepest undercut was detected in the lateral incisor region. Chung et al. ${ }^{18}$ measured buccal undercut depth both on СBCT images and direct during surgery, and found that buccal undercut depth was clinically higher from the CBCT measurements. The measurements were $0.2-0.6 \mathrm{~mm}$ lower in the СBCT images, despite the high correlation between two measurements. This is particularly important when placing the implant because of additional graft procedures may be necessary.

The relation of between alveolar ridge dimensions and buccal undercut has not been evaluated in other studies. According to our results, the depth of the buccal undercut increased when the height and coronal width of alveolar ridge increased in females. On the other hand the depth of the buccal undercut increased only when the coronal width of alveolar ridge increased in males.

This study was carried out in a Turkish subpopulation. Future investigation with different ethnic background is required. The region between the central incisors wasn't evaluated because a major anatomic structure; the incisive canal and foramen, is present in this region, thus possibly affecting the results.

\section{CONCLUSION}

The alveolar ridge dimensions had effect on buccal undercut. The buccal undercut depth increased when alveolar height and coronal alveolar width increased in females. On the other hand, it increased only when the coronal alveolar width increased in males.

\section{Conflict of interest statements}

The authors declare that they have no conflict of interest

\section{REFERENCES}

1. Consolaro A, Romano FL. Reasons for miniimplants failure: choosing installation site should be valued!. Dental Press J Orthod. 2014; 19:18-24.

2. Zhang W, Skrypczak A, Weltman R. Anterior maxilla alveolar ridge dimension and morphology measurement by cone beam computerized tomography (CBCT) for immediate implant treatment planning. BMC Oral Health 2015; 15:65.

3. Shapurian T, Damoulis PD, Reiser GM, Griffin TJ, Rand WM. Quantitative evaluation of bone density using the Hounsfield index. Int J Oral Maxillofac Implants 2006; 21:290-7.

4. Almasoud NN, Tanneru N, Marei HF. Alveolar bone density and its clinical implication in the placement of dental implants and orthodontic mini-implants. Saudi Med J 2016; 37:684-9.

5. Cassetta M, Sofan AAA, Altieri F, Barbato E. Evaluation of alveolar cortical bone thickness and 
density for orthodontic mini-implant placement. ] Clin Exp Dent 2016; 5:e245-52.

6. Hiasa K, Abe Y, Okazaki Y, Nogami K, Mizumachi W, Akagawa Y. Preoperative computed tomography-derived bone densities in Hounsfield Units at implant sites acquired primary stability. ISRN Dent 2011, Article ID 678729.

7. Hao Y, Zhao W, Wang Y, Yu J, Zou D. Assessments of jaw bone density at implant sites using 3D cone-beam computed tomography. Eur Rev Med Pharmacol Sci 2014; 18:1398-403.

8. Fuh L-J, Huang H-L, Chen C-S, Fu K-L, Shen Y-W, Tu M-G, Shen W-C, Hsu J-T. Variations in bone density at dental implant sites in different regions of the jawbone. J Oral Rehabil 2010; 37:346-51

9. Kim H-J, Yu S-K, Lee $\mathrm{M}-\mathrm{H}$, Lee $\mathrm{H}-\mathrm{J}$, Kim $\mathrm{H}-\mathrm{J}$, Chung $\mathrm{C}-\mathrm{H}$. Cortical and cancellous bone thickness on the anterior region of alveolar bone in Korean: a study of dentate human cadavers. J Adv Prosthodont 2012; 4:146-52.

10. Ozdemir F, Tozlu M, Germec Cakan D. Quantitative evaluation of alveolar cortical bone density in adults with different vertical facial types using cone-beam computed tomography. Korean J Orthod 2014; 44:36-43.

11. Çakur B, Sümbüllü MA, Harorlı A. Operasyon öncesi implant yerlerinin belirlenmesinde radyolojik kriterler ve radyolojik teknik seçimi. J Dent Fac Atatürk Uni 2007; 2:23-30.

12. Harris D, Buser D, Dula K, Gröndahl K, Harris D, Jacobs R, Lekholm U, Nakielny R, van Steenberghe $D$, van der Stelt P. EAO Guidelines for the use of Diagnostic Imaging in Implant Dentistry: A consensus workshop organized by the European Association for Osseointegration in Trinity College Dublin. Clin Oral Implants Res 2002; 13:566-70.

13. White SC, Pharoah M.J. Oral Radiology Principles and Interpretation. 7 st ed. St Louis, MO: Mosby Elsevier; 2014. p. 630-45.

14. Harris D, Horner K, Gröndahl K, Jacobs R, Ebba $H$, Benic GI, Bornstein MM, Dawood A, Quirynen M. EAO guidelines for the use of diagnostic imaging in implant dentistry 2011. A consensus workshop organized by the European Association for Osseointegration at the Medical University of Warsaw. Clin Oral Implants Res 2012; 23:1243-53.

15. Baumgaertel S, Hans MG. Buccal cortical bone thickness for mini-implant placement. Am J Orthod Dentofacial Orthop 2009; 136:230-5.
16. Choi JH, Yu HS, Lee KJ, Park YC. Threedimensional evaluation of maxillary anterior alveolar bone for optimal placement of miniscrew implants. Korean J Orthod 2014; 44:54-61.

17. Fayed MMS, Pazera P, Katsaros C. Optimal sites for orthodontic mini-implant placement assessed by cone beam computed tomography. Angle Orthod 2010; 80:939-51

18. Chung M-P, Wang I-C, Chan H-L, Wang H-L. Evaluation of Buccal Bone Concavity in the Esthetic Zone: A Cadaver Study. Implant Dent 2017; 26:751-5.

\section{Yazışma Adresi}

Uzm. Dt. Fatma Nur YILDIZ

Gazi Üniversitesi, Diş Hekimliği Fakültesi, Ağız, Diş ve Çene Radyolojisi A.D.

Emek, Ankara, Turkey.

Telephone number: 03122034157

e-mail: fn.yildiz89@gmail.com 